\title{
INTEGRALNOŚĆ MORALNOŚCI, KULTURY I GODNOŚCI CZLOWIEKA W GAUDIUM ET SPES SOBORU WATYKAŃSKIEGO II
}

\begin{abstract}
Wstęp
Moralność chrześcijańska, a w szczególności moralność katolicka odznacza się wewnętrzną spójnością, zewnętrznym ładem i pięknem. Mocno wpisuje się w kulturę katolicką i w życie Kościoła.

Moralność - rozumiana zarówno podmiotowo, jak i przedmiotowo - jest nieodłączna od człowieka, od jego myślenia, wyboru dobra lub zła, wartościowania moralnego, motywacji wszelkich działań oraz pośrednich i ostatecznych celów ludzkich. Moralność jest zatem integralną częścią każdej kultury, toteż bardzo trudno byłoby zrozumieć kulturę w oderwaniu od moralności. Człowiek jako osoba stanowi ową szczególną przestrzeń duchowo-cielesną, w której równocześnie urzeczywistnia się Kościół i cały możliwy świat wartości moralnych: ludzkich i chrześcijańskich ${ }^{1}$.

Niejako dopełnieniem moralności i kultury jest pojęcie godności człowieka, która wynika z faktu stworzenia i odkupienia. Godność staje się dla człowieka jedyną w swoim rodzaju norma normans. Samo pojęcie godności człowieka staje się kluczowe dla moralności, ukazując tym samym pozytywne kryteria określenia moralności i rozwoju osoby ${ }^{2}$.

Celem niniejszej publikacji jest ukazanie współzależności istniejącej pomiędzy moralnością katolicką i kulturą a godnością człowieka ukazaną w Konstytucji duszpasterskiej o Kościele w świecie współczesnym Gaudium et spes Soboru Watykańskiego II. Najpierw jednak podjęto próbę ukazania, że we wszystkich procesach kulturowych moralność staje się immanentnym elementem kultury.
\end{abstract}

\section{Integralność moralności i kultury}

Na początku warto przypomnieć, że moralność w każdej kulturze jest traktowana jako element nierozdzielnie z nią związany. Co więcej, wszystkie procesy należą do

1 W. Pieja, Moralność chrześcijańska $w$ zderzeniu z obojętnościa religijna, Tarnów 2018, s. 143; R.M. Pizzorni, Dio fondamento ultimo della morale e del diritto, „Sapienza” 49 (1996), s. 435-448.

2 Konstytucja duszpasterska o Kościele w świecie współczesnym ,, Gaudium et spes ” [dalej: KDK], w: Sobór Watykański II. Konstytucje, dekrety, deklaracje, Poznań 1968, nr 15. 
kulturotwórczych tylko wtedy, gdy tak pod względem treści, jak i sposobu ich przebiegania mają charakter dobrych pod względem etycznym. Jeżeli procesy te byłyby w jakikolwiek sposób złe albo służyły złu, przez to samo stawałyby się kulturowo destrukcyjne. Samo słowo „moralność” pochodzi od łacińskiego rzeczownika mors - «zwyczaj, obyczaj» ${ }^{3}$.

Do dziedziny moralności zalicza się wszystko to, co dana grupa lub poszczególni jej przedstawiciele w określonym środowisku społecznym i historyczno-kulturowym uważają za podlegające kryteriom dobra albo zła. Mianem moralności, albo też jak się dziś coraz częściej mówi: ethosu, określa się także praktykę moralną danej społeczności. We wszystkich przypadkach moralność dotyczy ludzi, ich postaw, sądów i przeżyć. Nie obejmuje jakiegoś jednego tylko wycinka życia, lecz całe działanie ludzkie, na ile jest rozumne, wolne i odpowiedzialne. Wiąże się z każdą ludzką myślą i każdym czynem. Czyn moralny (actus humanus) - w przeciwstawieniu do czynu pozamoralnego (actus homnis) - odsłania się w doświadczeniu osoby bądź to jako czyn moralnie dobry albo zły, bądź to jako czyn, który powinien albo nie powinien być spełniony. Zgodnie z tym mówi się o moralności, gdy rozważa się dobro czy zło moralne lub powinność moralną. Pytanie zatem o definicję moralności od razu przekształca się $\mathrm{w}$ pytanie o to, co stanowi istotę dobroci i powinności moralnej czynu. Trzeba określić, przez co dobro lub zło czynu staje się dobrem albo złem moralnym i przez co powinność spełnienia czynu staje się powinnością moralną. Etyka udziela na to pytanie trzech różnych odpowiedzi w zależności od swojej orientacji ideowej: filozoficznej lub religijnej .

3 Moralność jest objawem wszelkich działań i postaw ludzkich, Orzeka się o nich z punktu widzenia ich moralnej powinności lub wartości. Również osobie - jako sprawcy tych działań i podmiotu postaw - przysługuje określenie „moralny” lub „niemoralny”. Tak rozumiana moralność stanowi przedmiot etyki, a także teologii moralnej. Niewłaściwe zatem jest często stosowane w mowie potocznej utożsamianie terminów „,moralność” i „,etyka”. Natomiast praktykowane na ogół zamienne używanie przymiotników: „moralny” i ,etyczny” (np. czyn moralny, czyn etyczny), a także przeciwstawnych im: ,amoralny” i „nieetyczny”, jest dopuszczalne. Podobnie zwykło się utożsamiać moralność z etosem, co wielu teoretyków rozumie niejednakowo. H. Juros, Moralność, w: Słownik teologiczny, red. A. Zuberbier, Katowice 1998, s. 314-316.

4 Szerzej m.in.: B Haring, Moralność jest dla ludzi. Etyka chrześcijańskiego personalizmu, Warszawa 1975; S. Witek, Chrześcijańska wizja moralności, Poznań 1982; S. Olejnik, W kręgu moralności chrześcijańskiej, Warszawa 1985; J.M. Aubert, Jak żyć po chrześcijańsku w XX wieku?, Warszawa 1986; Moralność chrześcijańska, t. 2, red. P. Góralczyk, Poznań-Warszawa 1987; S. Rosik, Wezwania i problemy moralne. Refleksje teologiczno-moralne, Lublin 1992; J. Galarowicz, Powołani do odpowiedzialności. Elementarz etyczny, Kraków 1993; T. Pinckaers, Źródła moralności chrześcijańskiej. Jej metoda, treść, historia, Poznań 1994; F. Greniuk, Wspólnotowy charakter moralności Ludu Bożego, „Roczniki Teologiczno-Kanoniczne” 24 (1977), z. 3, s. 39-49; F. Greniuk, Współczesna teologia grzechu, „Roczniki Teologiczno-Kanoniczne” 32 (1985), z. 3, s. 81-102; J. Nagórny, Teologiczna interpretacja moralności Nowego Przymierza, Lublin 1989. 
Jest rzeczą charakterystyczną, że soborowy wykład moralności międzyludzkiej, społecznej, międzynarodowej mocno uwydatnia wartość osoby, która jest podmiotem moralności. Występuje ona tutaj nie tylko jako podmiot, ale przede wszystkim jako zupełnie swoista wartość przedmiotowa, wedle której należy kształtować postępowanie w różnych dziedzinach i profilach życia współczesnego świata. W czasach współczesnych do głosu dochodzi moralność, a wraz z nią etyka, której przysługuje określenie „personalistyczna”.

$\mathrm{Na}$ temat moralności ludzkiej i chrześcijańskiej wypowiadają się wszystkie dokumenty Soboru Watykańskiego II. Niemniej w zarysowaniu problemu należy podkreślić, że ważne analizy na temat człowieka jako podmiotu moralności znajdują się przede wszystkim w Konstytucji duszpasterskiej o Kościele w świecie współczesnym $^{5}$. Gaudium et spes porusza kwestię godności człowieka, jego rozumności i mądrości ${ }^{6}$, głębi ludzkiego sumienia ${ }^{7}$, wielkiego znaczenia wolności i tajemnicy ludzkiego doskonalenia się ${ }^{8}$. Stwierdza, że „Pan Jezus, Boski Nauczyciel i Wzór wszelkiej doskonałości, głosi swoim uczniom - ludziom wszelkiego stanu - wszystkim razem i każdemu z osobna - świętość życia”, że „nakazy prawa Bożego rozpoznaje człowiek za pośrednictwem swego sumienia”" ${ }^{10}$ że „społeczność wiernych, obdarzona bogactwami kultury własnego narodu, powinna głęboko zapuścić korzenie w lud, aby powstawały rodziny przeniknięte duchem Ewangelii" ${ }^{\prime 1}$. Konstytucja Gaudium et spes, wspominając o doświadczeniu grzechu ${ }^{12}$, o tym, że „grzech pomniejsza człowieka, czy to w stosunku do siebie samego, czy do innych ludzi i wszystkich rzeczy stworzonych", przekonuje, że „w świetle Objawienia znajduje swoje ostatecznie wyjaśnienie i zarazem doniosłe powołanie, jak głęboka jest nędza, których człowiek doświadcza"13. W rozdziale drugim tejże konstytucji mowa jest o „wspólnotowym charakterze powołania (moralności) człowieka”"14, o wzajemnej zależności osoby ludzkiej i społeczeństwa ${ }^{15}$, o popieraniu wspólnego dobra ${ }^{16}$. Rozdział trzeci Gaudium et spes przedstawia „aktywność ludzką w świecie, będąc tym samym historiozbawczym wykładem na temat szeroko rozumianej moralności

5 KDK 14.

6 KDK 15.

7 KDK 16.

8 KDK 17.

9 Konstytucja dogmatyczna o Kościele „Lumen gentium” [dalej: KK], w: Sobór Watykański II. Konstytucje, dekrety, deklaracje, dz. cyt., $\mathrm{nr} 40$.

${ }^{10}$ Deklaracja o wolności religijnej „, Dignitatis humanae” [dalej: DWR], w: Sobór Watykański II. Konstytucje, dekrety, deklaracje, dz. cyt., nr 3.

${ }^{11}$ Dekret o działalności misyjnej Kościoła „Ad gentes divinitus” [dalej: DDM], w: Sobór Watykański II. Konstytucje, dekrety, deklaracje, dz. cyt., nr 15.

12 KDK 13.

13 KDK 13.

14 KDK 24.

15 KDK 25.

${ }^{16}$ KDK 26, 65-68, 7. 
społecznej, łącznie z opisem czynników alienujących współczesnego człowieka ${ }^{17}$. Rozdział czwarty, zatytułowany Zadania Kościoła w świecie współczesnym, określa najważniejsze relacje zachodzące między Kościołem a światem ${ }^{18}$. Część druga Gaudium et spes jest przedstawieniem „niektórych bardziej palących problemów” ${ }^{19}$, do których sobór zalicza „poparcie należne godności małżeństwa i rodziny” (tu można odnaleźć nowatorskie naświetlenie życia rodzinnego) ${ }^{20}$, potrzebę „należytego podnoszenia poziomu kultury"21 oraz wiele szczegółowych kwestii z zakresu życia gospodarczo-społecznego. Po soborze problemy te zostały szczegółowo naświetlone zwłaszcza w papieskich dokumentach społecznych i podczas papieskich pielgrzymek na wszystkie kontynenty świata. Sygnalizując tutaj, czym jest moralność w obszarze kultury i czym jest kultura dla moralności, można zauważyć, że wspólnym pojęciem personalistycznym - niestety mało później omawianym, a mającym swe wielkie znaczenie zarówno dla moralności, jak i kultury - jest pojęcie dojrzałości. Dojrzałość ludzka to „stałość ducha, zdolność podejmowania odpowiedzialnych decyzji oraz właściwy sposób osądzania zdarzeń i ludzi”22.

We wprowadzeniu do zagadnienia moralności warto wskazać na słowa klucze, pozwalające na właściwe jej zrozumienie w duchu soboru. W tym kontekście można wymienić podstawowy dar i zadanie chrześcijanina: „słuchając Bożego Słowa - wierzyć, wierząc - ufać, ufając - miłować"23. Poważnym problemem moralnym dzisiejszego świata jest ateizm i agnostycyzm ${ }^{24}$. Godną człowieka odpowiedzią na owe postawy jest autentyczne apostolstwo wszystkich ochrzczonych ${ }^{25}$. Pamiętając o autonomii rzeczywistości stworzonej przez Boga $^{26}$, chrześcijanie mają niezbywalne prawo głoszenia Ewangelii, zwłaszcza poprzez osobiste świadectwo życia i dialog 27 .

17 KDK 31, 33-39.

18 KDK 40-45.

19 KDK 46-91.

20 KDK 47-52.

21 KDK 53-62.

${ }^{22}$ Dekret o formacji kapłańskiej „,Optatam totius” [dalej: DFK], w: Sobór Watykański II. Konstytucje, dekrety, deklaracje, dz. cyt., nr 11; Deklaracja o wychowaniu chrześcijańskim ,, Gravissimum educationis”, w: Sobór Watykański II. Konstytucje, dekrety, deklaracje, dz. cyt., nr 2.

${ }^{23}$ Konstytucja dogmatyczna o Objawieniu Bożym „Dei verbum” [dalej: KO], w: Sobór Watykański II. Konstytucje, dekrety, deklaracje, dz. cyt., nr 1.

${ }^{24}$ KDK 19-21, 57.

${ }^{25}$ Dekret o apostolstwie świeckich „,Apostolicam actuositatem” [dalej: DAŚ], w: Sobór Watykański II. Konstytucje, dekrety, deklaracje, dz. cyt., nr 1-17; KK 33; KDK 43.

${ }^{26}$ KDK 36-41, 71-76.

${ }^{27}$ KO 1; KDK 19, 46; DFK 19; Dekret o ekumenizmie ,,Unitatis redintegratio” [dalej: DE], w: Sobór Watykański II. Konstytucje, dekrety, deklaracje, dz. cyt., nr 4, 11, 23. 
Wśród dóbr duchowych, będących także dobrami kultury, bez wątpienia w centrum leżą te dobra, które określa się mianem sakramentów ${ }^{28}$. Ich znaczenie dla życia moralno-kulturowego ma jeszcze głębszy sens, gdy spełniane są w „duchu ustawicznej modlitwy" ${ }^{29}$. Zarysowując obszar problemów moralnych, jakimi zajmuje się sobór, nie wolno też zapomnieć o poruszanych w wielu dokumentach zagadnieniach aretologicznych. Mowa jest o „,notach Boskich" 30 , o cnotach ewangelicznych (rodzinnych) ${ }^{31}$, kardynalnych ${ }^{32}$ oraz uzdalniających człowieka nawet do męczeństwa $^{33}$. W ramach moralności nie można też pominąć takich ludzkich doświadczeń jak cierpienie ${ }^{34}$ i śmierć, pokonana zbawczą śmiercią Chrystusa Zmartwychwstałe$\mathrm{go}^{35}$. Można powiedzieć, że w całej szerokiej i wnikliwej doktrynie soboru moralność, kultura i natura ludzka są ze sobą najściślej powiązane. „Człowiek stanowiący jedność ciała i duszy skupia w sobie dzięki swej cielesnej naturze elementy świata materialnego, tak że przez niego dosięgają one swego szczytu i wznoszą głos w dobrowolnym chwaleniu Stwórcy. Nie wolno więc człowiekowi gardzić życiem ciała, lecz przeciwnie, powinien on uważać ciało swoje, jako przez Boga stworzone i mające być wskrzeszone w dniu ostatecznym, za dobre i godne szacunku. Ale człowiek zraniony przez grzech doświadcza buntów ciała. Sama godność człowieka wymaga, aby wysławiał Boga w swoim ciele, a nie dozwalał, by ono wysługiwało się złym skłonnościom jego serca. Nie myli się człowiek, gdy uważa się za wyższego od rzeczy cielesnych, a nie tylko za cząstkę przyrody lub za anonimowy składnik społeczności państwowej. Albowiem tym, co zawiera jego wnętrze, przerasta człowiek cały świat rzeczy, a wraca do tych wewnętrznych głębi, gdy zwraca się do swego serca, gdzie oczekuje go Bóg, który bada serce, i gdzie on sam pod okiem Boga decyduje $\mathrm{o}$ własnym losie. Tak więc uznając $\mathrm{w}$ sobie duszę duchową i nieśmiertelną, nie daje się zwieść ułudną fikcją wypływającą z fizycznych tylko i społecznych warunków, lecz przeciwnie, dosięga samej prawdziwej istoty rzeczy"36.

${ }^{28}$ DWR, nr1; KDK 5, 45; KK 1, 9; Konstytucja o liturgii „, Sacrosanctum Concilium” [dalej: KL], w: Sobór Watykański II. Konstytucje, dekrety, deklaracje, dz. cyt., nr 47-48, 72; Dekret o Kościołach wschodnich katolickich „Orientalium Ecclesiarum”, w: Sobór Watykański II. Konstytucje, dekrety, deklaracje, dz. cyt., nr 12; DFK 5.

${ }^{29} \mathrm{KK} 10,40$; KL 53-54.

${ }^{30} \mathrm{KO} 1$.

31 KK 41.

${ }^{32}$ KK 41; KDK 30, 43; DAŚ 4.

${ }_{33}$ KK 42; DWR 14; DE 4, 14.

34 KK 8.

35 KDK 22; DDM 25; Deklaracja o stosunku Kościoła do religii niechrześcijańskich „Nostra aetate”, w: Sobór Watykański II. Konstytucje, dekrety, deklaracje, dz. cyt., nr 4.

${ }^{36}$ H. Juros, Moralność, art. cyt., s. 14; W. Chudy, Miejsce prawdy w systemie wartości. Postawa klasyczna a postawa liberalistyczna i ich konsekwencje aksjologiczne, „Chrześcijanin w Świecie” 23 (1993), nr 2, s. 5-62; W. Chudy, Między wolnościa prawdziwa a zniewoleniem, „Chrześcijanin w Świecie” 24 (1994), nr 2-3, s. 110-121; W. Czamara, Stabość moralna współczesnego człowieka a szansa jego moralnej odnowy w ujęciu papieża Jana 


\section{Doświadczenie godności czlowieka}

Ważnym pojęciem w całym soborowym nauczaniu jest kluczowe dla moralności pojęcie godności człowieka ${ }^{37}$. Godność staje się dla człowieka jedyną w swoim rodzaju norma normans ${ }^{38}$. Bóg w swojej mądrości i miłości stworzył dobry świat i człowieka, którego uznał za „bardzo dobrego” (Rdz 1, 31). Zgodnie z dwoma opisami stworzenia człowiek właśnie stanowi szczyt i ośrodek natury. Przyroda zaś zostaje poddana osobie ludzkiej jako teren do pracy. Bóg obdarza człowieka swoim tchnieniem, dlatego też odbija on Jego doskonałośćc ${ }^{39}$.

Akt stwórczy Pana Boga, wynikający z Jego nieskończonej dobroci względem stworzenia, zobowiązuje człowieka do udzielenia odpowiedzi także na fundamencie miłości. Biblijne pojęcie obrazu Bożego w człowieku oznacza przede wszystkim istnienie człowieka jako osoby, to znaczy jako istoty, która różni się od wszystkich istot materialnych tym, że jest panem siebie i świadomie kieruje sobą. Warto podkreślić, że człowiek jest jednością psychofizyczną, ciałem i duszą jednocześnie. Tylko człowiek jako osoba jest w stanie przyjąć Boże wezwanie i odpowiedzieć na nie. Odpowiedź ta wyraża się m.in. w relacji człowieka do świata, ujawnia się w jego wolnym i odpowiedzialnym panowaniu nad stworzeniami. Wolność polega na zdolności opowiedzenia się za Bogiem lub przeciw Niemu. Najwyższym udziałem w wolności Bożej jest działanie całkowicie zgodne z wolą Bożą. Człowiek, wzrastając w wolności, wzrasta w człowieczeństwie, natomiast zniewala się, zrywając dialog z Bogiem ${ }^{40}$.

Jak naucza Gaudium et spes: „Godność człowieka wymaga, aby działał ze świadomego i wolnego wyboru, to znaczy osobowo, od wewnątrz poruszony i naprowadzony, a nie pod wpływem ślepego popędu wewnętrznego lub też zgoła przymusu zewnętrznego. Taką zaś wolność zdobywa człowiek, gdy uwalnia się od wszelkiej niewoli namiętności, dąży do swego celu drogą wolnego wyboru dobra oraz zapewnia sobie skutecznie i pilnie odpowiednie pomoce" ${ }^{41}$.

Pawta II, w: Vivere in Christo. Chrześcijański horyzont moralności. Księga pamiatkowa ku czci Księdza Profesora Seweryna Rosika w 65. rocznicę urodzin, red. J. Nagórny, A. Derdziuk, Lublin 1996, s. 345-369; J. Czarny, Jana Pawła II wizja cywilizacji miłości. Studium filozoficzne, Wrocław 1994.

37 KDK 15.

38 S. Bezner, Norma personalistyczna jako „norma normans” moralności $w$ nauczaniu K. Wojtyty, Katowice 2006, s. 43.

39 Por. S. Smoleński, Powołanie chrześcijańskie. Zarys teologii moralnej, t. 1, Kraków 1978, s. 56.

${ }^{40}$ KDK 17; S. Smoleński, Powołanie chrześcijańskie..., dz. cyt. s. 53; W. Granat, Personalizm chrześcijański, Poznań 1985, s. 55-60.

${ }^{41}$ KDK 41; por. W. Granat, Personalizm chrześcijański, dz. cyt, s. 593. Ważnym dokumentem broniącym godności osoby ludzkiej jest niewątpliwie Deklaracja praw człowieka, która stwierdza, że ,godność polega na równości praw wszystkich ludzi, na zakazie niewolnictwa, zakazie tortur i nieludzkiego traktowania, na posiadaniu odpowiedniej ochro- 
Z racji stworzenia człowiek otrzymuje wspaniałe dary, trwa w przyjaźni z Bogiem i prowadzi z Nim dialog. „Człowiek jest bytem, do którego Bóg może powiedzieć «Ty», a jako Boski obraz utrzymuje z Nim osobową relację"42. Owa życiodajna relacja $z$ Bogiem wypływa $z$ istoty człowieczeństwa i stanowi warunek pełni człowieczeństwa. A zatem osoba ludzka, odłączając się od Boga, narusza swój fundament. Bóg tymczasem wciąż zaprasza człowieka do życia z sobą, do chwały będącej dla niego prawdziwym szczęściem. Dla Karola Wojtyły - tak jak dla wszystkich personalistów - godność człowieka jest pojęciem kluczowym i wartością podstawowąa $^{43}$. Konstytucja Gaudium et spes szeroko rozwija ten wątek i podkreśla, że życie człowieka ma być pełne, wolne, godne w kontekście współczesnego świata ${ }^{44}$. „Godność człowieka polega i na tym, że przerasta on cały świat rzeczy i posiada duszę duchową i nieśmiertelną, korzysta z władz rozumu i zdobywa prawdę i mądrość. Godność człowieka ujawnia się przez sumienie, które jest wewnętrznym sanktuarium człowieka, gdzie przebywa on sam z Bogiem" "45. Godność ludzka tkwi w Bogu i dzięki Niemu się rozwija. Ponadto samo wcielenie Jezusa Chrystusa nobilituje i wywyższa ludzką godność, przywracając jej charakter nadprzyrodzony ${ }^{46}$. Szanując godność każdej osoby, trzeba definitywnie potępić wszelkie przejawy demoralizacji. Godność wyznacza więc wszystkie granice złego postępowania. Ponadto owe graniczne kryteria wyznaczają istotnie cały obszar normatywny dla postępowania człowieka. Godność bowiem istoty ludzkiej wpisuje się we wszystkie obszary ludzkiego działania. „Godność osobista i wolność człowieka da się zabezpieczyć przez Ewangelię Chrystusową, która święcie szanuje godność sumienia i wolną jego decyzję"47.

ny prawnej, na wolności myśli, sumienia i religii, na ochronie życia prywatnego, prawie do pracy, do odpowiedniej stopy życiowej”. Zob. Powszechna deklaracja praw człowieka (przyjęta i proklamowana rezolucja Zgromadzenia Ogólnego ONZ 217 A (III) w dniu 10 grudnia 1948), art. 1-30, amnesty.org.pl/wp-content/uploads/2016/04/Powszechna_Deklaracja_Praw_Czlowieka.pdf [dostęp: 10 VI 2020 r.].

42 S. Smoleński, Powołanie chrześcijańskie..., dz. cyt. s. 53.

43 Trzeba od razu powiedzieć, że norma normans moralności jest niezbywalnie włączona właśnie w godność człowieka. Jan XXIII w Pacem in terris przedstawia poziomy godności ludzkiej, wyodrębniając działanie rozumu i woli oraz status dziecięctwa Bożego. Papież ten stwierdza, że wszyscy ludzie posiadają godność na fundamencie natury ludzkiej. Ich zadanie zatem polega na tym, aby żyć i postępować zgodnie z naturą ludzką. Jan XXIII, Pacem in terris, Kraków 2003, nr 1, 2, 4, 14, 20.

44 KDK 17.

45 KDK 16.

46 W. Granat, Personalizm chrześcijański, dz. cyt., s. 563.

${ }^{47}$ KDK 41. K. Wojtyła akcentuje także szczególną godność rodzicielską. Ponadto należy zwrócić uwagę na godność człowieka w kontekście gospodarczo-społecznym i prawno-politycznym, aby w ten sposób budować trwały pokój. Godność wyznacza także wolność religijną, o czym powinni pamiętać misjonarze. Nie bez znaczenia jest również i to, że kwestia ta znalazła się w Deklaracji o wychowaniu chrześcijańskim i Deklaracji o stosunku do religii niechrześcijańskich. Paweł VI w Liście apostolskim Octogesima adve- 
Sprawa godności człowieka nie jest nowa w antropologii i w etyce. Św. Tomasz zaznacza, że człowiek, uczestnicząc w życiu Boga, osiąga własną autoteleologię, z tychże więc racji przysługuje mu niezbywalna godność ${ }^{48}$. Sobór Watykański II przypomina o godności ciała, gdyż jest ono stworzone przez Boga oraz przeznaczone do zmartwychwstania. Trzeba także pamiętać, że ,człowiek jako całość psychofizyczna ma swoją podwójną wartość: naturalną i nadprzyrodzoną"49.

Z racji godności stwórczo-zbawczej człowiek jako osoba stanowi ognisko wolności sprawczej oraz ognisko relacji w stosunku do rzeczy, osób i Boga. K. Wojtyła podkreśla często istnienie jedności między osobą a osobowością, czyli między „,ja” podejmującym decyzje a ,ja” kształtującym się w wyniku podejmowanych decy$\mathrm{zji}^{50}$. Mówiąc o godności osoby ludzkiej, trzeba zaznaczyć, że to ona leży u podstaw

niens postuluje, aby każdej osobie i w każdej rodzinie przysługiwał godny stan materialny, społeczny, kulturalny, duchowy. Ma on na myśli zasadę godnej troski i wyjątkowej ochrony osób wyrzuconych na margines życia społecznego. Za: W. Granat, Personalizm chrześcijański, dz. cyt. s. 564-569 (zob. podaną tam bibliografię).

48 Za: W. Granat, Personalizm chrześcijański, dz. cyt. s. 569-576.

${ }^{49}$ KDK 17. Ks. W. Granat pisze: „Człowiek jak istota rozumna jest sam przestrzenią, która wszechświat ogarnia. Człowiek panuje nad czasem, przewidując na podstawie praw przyrody pewne fakty. Osoba ludzka reflektuje ponadto nad możliwością życia wiekuistego. Albowiem każdy byt umysłowy pragnie być zawsze, i nie jest to pragnienie próżne. Św. Tomasz tłumaczy, że rozum i ręce pozwalają tworzyć nieograniczone formy, a przez to osiągać nieograniczone skutki. A zatem człowiek wciąż przekracza rozmaite granice, humanizując ziemię, czyniąc ją sobie poddaną. Osoba kieruje się w swym postępowaniu głosem sumienia, głosem rozumu naturalnego. Istota ludzka jako istota rozumna jest W stanie planować i porządkować rzeczywistość, przyczyniając się do dobra wspólnego. Człowiek ma możliwość stanąć obok siebie, ocenić krytycznie własne czyny. Umysł ludzki ciągle przełamuje bariery stawiane na drodze jego dążeń ku prawdzie, rozum ludzki może się wznieść do poznania Boga osobowego, i to jest jego godność [...]. Z rozumem łączy się mądrość skłaniająca do prawdy, dobra i szukania rzeczy ponad widzialnym światłem, a także dążność do humanizacji świata [...]. A zatem człowiekowi przysługuje godność, ponieważ jest bytem rozumnym. Człowiek jako istota wolna odrzuca fatum, przeznaczenie, przymus. Wolność woli jako wielka siła kształtuje naturę ludzką oraz wyznacza relację do świata i Boga. Wolność człowieka jest podobieństwem do samego Boga i wynosi człowieka ponad świat materialny koniecznych przyczyn i skutków. Wolność wreszcie, osłabiona przez grzech, zostaje uzdrowiona przez Chrystusa. Człowiek ze swej natury dąży ku dobru absolutnemu, pragnie przestrzeni przepełnionej Bogiem. Prawdziwa wolność jest nacechowana poczuciem obowiązku oraz odpowiedzialności. Wolność musi być pielęgnowana i wychowywana. Warto zaznaczyć, że siłą wolności jest siła samo-determinizmu. Osoba ludzka okazuje Bogu posłuszeństwo właśnie aktem wolnej woli, co podkreślił Sobór Watykański I i powtórzył Sobór Watykański II. A zatem człowiekowi przysługuje godność, ponieważ jest bytem posiadającym wolną wolę. Por. W. Granat, Personalizm chrześcijański, dz. cyt., s. 571-576.

50 K. Wojtyła, Osoba i czyn, Kraków 1969, s. 109. 
osobowej norma normans ${ }^{51}$. „Norma zakazująca zakazuje wszelkiego popadania w niegodziwość, norma nakazująca nakazuje czynić to, co jest godziwe; a czego zaniechanie byłoby niegodziwe, norma pozwalająca pozwala czynić, cokolwiek jest godziwe, a zarazem nie czynić tego wszystkiego, czego zaniechanie nie jest niegodziwe, wreszcie norma konsultatywna doradza wybierać w działaniu zawsze to, co najchwalebniejsze, odradza zaś ewentualności mniej chwalebne" 52 . Godność osoby ludzkiej to wartość podstawowa, wewnętrzna, mająca pierwszeństwo w konfliktach aksjologicznych. Ma ona charakter trwały, wrodzony, dotyczy wszystkich jednostek ludzkich i przez to może być nazwana norma normans ${ }^{53}$.

Vaticanum II raz po raz uwypukla prawdę, że godność człowieka została niezmiernie pogłębiona w świetle objawienia, które pozwala człowiekowi poznać Boga, a także siebie samego. Bóg zbawia człowieka na fundamencie miłości i przebaczenia, oczekując ludzkiej odpowiedzi wyrażającej się w miłości i nawróceniu. Człowiek staje przed Bogiem jako zależny od Niego, lecz równocześnie wolny, odpowiedzialny, tworzący kulturę, obdarzony godnością i niepowtarzalnością. Objawienie jest źródłem antropologii teologicznej, gdyż „człowiek został przez Boga przeznaczony do określonego celu, który nadaje sens jego istnieniu" ${ }^{54}$. Cel ten może być zrealizowany dzięki właściwościom ludzkiej natury i dzięki łasce. Bóg powołał człowieka, aby stanął on wobec świata i ludzkości. Powołanie to ma charakter normatywny i zobowiązujący, pozwala właściwie wartościować ludzkie czyny i dążenia w stosunku do Boga, człowieka i świata. Doświadczenie godności otwiera już teraz powołanie człowieka, także powołanie do pełnego uczestnictwa w Kościele i w kulturze. Co więcej, powołanie to staje się źródłem ludzkiej moralności. Elementem istotnym powołania jest ustanowienie człowieczeństwa aktem woli Bożej i w kontekście daru boskiej miłości. Dar natomiast zobowiązuje do dawania odpowiedzi miłującemu Dawcy. Godność wpisuje się w powołanie chrześcijańskie i w uczestnictwo „w Chrystusie” (en Christo). „Enchrystia” uwypukla zarówno naturalne, jak i nadprzyrodzone wymiary godności. Powołanie w całym swym wymiarze ma związek z osobą i dziełem Chrystusa. Jest powołaniem chrześcijańskim, skierowanym jednak do wszystkich ludzi. Teologia moralna jest teologią powołania chrześcijańskiego ${ }^{55}$. „Człowiek, będąc jedynym na ziemi stworzeniem, którego Bóg chciał dla niego samego, nie może odnaleźć się w pełni inaczej jak tylko poprzez bezinteresowny dar

51 Por. szerzej: S. Bezner, Norma personalistyczna ..., dz. cyt., s. 46-49. M. Drożdż, Osoba i media. Personalistyczny paradygmat etyki mediów, Tarnów 2005, s. 50-54.

52 A. Rodziński, Osoba, moralność, kultura, Lublin 1989, s. 96.

53 J. Galarowicz, Człowiek jest osoba. Podstawy antropologii filozoficznej Karola Wojtyty, Kraków 1994; J. Galarowicz, Imię własne człowieka. Klucz do myśli i nauczania Karola Wojtyły - Jana Pawła II, Kraków 1996; J. Gałkowski, Osoba i wspólnota, ,Roczniki Nauk Społecznych" 8 (1980), s. 49-74; J. Gałkowski, O podmiotowym charakterze wspólnoty w ujęciu kard. K. Wojtyty, „Zeszyty Naukowe KUL” 26 (1983), nr 4, s. 3-17.

54 S. Smoleński, Powołanie chrześcijańskie..., dz. cyt., s. 46.

55 S. Smoleński, Powołanie chrześcijańskie..., dz. cyt., s. 47-48. 
z siebie samego" 56 . Godność osoby ludzkiej jest wartością uniwersalną, centralną i absolutną. Ma charakter wrodzony, trwały, niezbywalny i zobowiązujący ${ }^{57}$.

Treść powołania oraz warunki, w jakich jest ono realizowane, wyznaczają strukturę całej moralności. Powołanie w świetle objawienia jest procesem historycznym, począwszy od stworzenia człowieka, aż do jego zbawienia realizowanego w Kościele Chrystusowym. Człowiek bowiem podlega nieustannemu uświęcaniu przez sakramenty powodujące wzrost wiary i miłości. W ten sposób osoba ludzka uzdalnia się do udzielenia odpowiedzi na dar powołania.

Zrozumienie powołania jest zrozumieniem istoty dobra moralnego, a przez to poznaniem także najważniejszych zasad religijno-moralnych. Warto zaznaczyć, że powołanie dokonuje się na rozmaitych etapach i w różnych sytuacjach życiowych osoby ludzkiej. Struktura powołania ma charakter dedukcyjny, gdy przedstawia reguły działania obowiązujące w każdych warunkach, ma też charakter indukcyjny, gdy na podstawie warunków egzystencji ludzkiej ukazuje szczegółowe normy postępowania. $\mathrm{W}$ ten sposób powołanie staje się najważniejszym procesem zarówno eklezjo-, jak i kulturotwórczym.

Godność rozumie się także jako doskonałość zrodzoną w działaniu moralnie wartościowym oraz jako rezultat wychowania i własnego wysiłku. Trzeba zaznaczyć, że godność osobowościową, osobistą można w jakimś stopniu stracićs ${ }^{58}$. Człowiek jest zarówno bytem natury, jak i kultury, która jest właściwym sposobem bytowania oraz istnienia osoby ludzkiej. Podstawowym wymiarem kultury jest zdrowa moralność. „Człowiek jest przedmiotowo «kimś» - i to go wyodrębnia wśród reszty bytów widzialnego świata, które przedmiotowo są zawsze tylko «czymś»" go nie można traktować człowieka jako rzeczy wśród innych rzeczy. W doświadczeniu osoba ujawnia się od strony osobnej wartości, godności osobowej. Osoba dana jest wprost, bezpośrednio oraz intuicyjnie. Etyka personalistyczna podkreśla normatywny charakter godności osoby ludzkiej. K. Wojtyła naucza, że osoba musi być traktowana jako cel sam w sobie, a nie środek używania. Do każdego człowieka trzeba odnosić się zawsze z miłością ${ }^{60}$. $Z$ tego samego powodu A. Rodziński stwierdza, że osoba jest wartością pierwszą, stanowi punkt odniesienia dla wszystkich innych

56 KDK 24.

${ }^{57}$ H. Langkammer, Godność człowieka według Biblii, w: Życie społeczne w Biblii, red. G. Witaszek, Lublin 1997, s. 9-21; I. Mroczkowski, Wolność na miarę wiary, nadziei i miłości, „Chrześcijanin w Świecie” 20 (1988), nr 4-5 s. 102-117; I. Mroczkowski, Misterium człowieka stworzonego, „Roczniki Teologiczne” 40 (1993), z. 3, s. 31-40; J. Nagórny, Trynitarny fundament życia moralnego w ujęciu św. Pawła, „Rocznik Teologii Katolickiej” 39 (1982), s. 47-56; J. Nagórny, Kazanie na górze (Mt 5-7) jako moralne orędzie Nowego Przymierza, „Rocznik Teologii Katolickiej” 32 (1985), z. 3, s. 5-21.

58 F. Mazurek, Godność osoby ludzkiej jako źródło praw człowieka i obywatela, „Civitas et Lex" (2014), nr 1, s. 41-47.

59 F. Mazurek, Godność osoby..., art. cyt. s. 48-49.

${ }^{60}$ F. Mazurek, Godność osoby..., art. cyt. s. 49; K. Wojtyła, Osoba i czyn, dz. cyt., s. 24. 
wartości. „Sumienie, będąc źródłem samoinformacji o zgodności z przedmiotową normą, staje się subiektywną i ostateczną normą moralności. Normą moralności jest godność osoby ludzkiej. Norma wskazuje na sposób afirmowania osoby. Z tego powodu wartość osoby i jej godność staje się czymś powinnościorodnym. Staje się też podstawą antropologiczno-moralną zasady, że człowieka nigdy nie wolno traktować instrumentalnie ${ }^{61}$. Jest to niezbywalna zasada zasad dla wszelkich teorii kultury i w jej ramach - wszelkich teorii moralnych, które pretendują do tego, aby nosić miano humanistycznych ${ }^{62}$.

\section{Zakończenie}

Podsumowując, warto przywołać tekst Gaudium et spes mówiący o godności rozumu, prawdzie i mądrości człowieka: „Człowiek słusznie sądzi, że uczestnicząc w świetle Bożej myśli, góruje swym rozumem nad światem rzeczy. Na przestrzeni wieków, dzięki pilnemu ćwiczeniu swego twórczego ducha, postąpił niewątpliwie w naukach doświadczalnych, w umiejętnościach technicznych i w sztukach wyzwolonych. W naszych czasach zaś doszedł do wybitnych osiągnięć, zwłaszcza w badaniu i podporządkowaniu sobie świata materialnego. Zawsze jednak szukał prawdy głębszej i znajdował ją. Umysł bowiem nie jest zacieśniony do samych zjawisk, lecz może z prawdziwą pewnością ująć rzeczywistość poznawalną, mimo że w następstwie grzechu jest częściowo przyciemniony i osłabiony. Na koniec natura intelektualna osoby ludzkiej udoskonala się i powinna doznać udoskonalenia przez mądrość, która umysł człowieka łagodnie pociąga ku poszukiwaniu i umiłowaniu tego, co prawdziwe i dobre. Przepojony nią człowiek dochodzi poprzez rzeczy widzialne do niewidzialnych. Epoka nasza bardziej niż czasy ubiegłe potrzebuje takiej mądrości, która by wszelkie rzeczy nowe, jakie człowiek odkrywa, czyniła bardziej ludzkimi. Przyszłym losom świata grozi bowiem niebezpieczeństwo, jeśli ludzie nie staną się mądrzejsi. A zaznaczyć jeszcze trzeba, że liczne narody mniej zasobne ekonomicznie, a bogatsze w mądrość mogą innym przynieść niezwykle wiele pożytku. Dzięki darowi Ducha Świętego dochodzi człowiek przez wiarę do kontemplacji i pojmowania tajemnicy planu Bożego" ${ }^{63}$.

Byłoby wskazane, aby ową integralność moralności i kultury opartej na godności osoby ludzkiej ukazać w sposób merytoryczny, logiczny i metodyczny w nowej publikacji jako „moralność nowego życia w Chrystusie”.

${ }^{61}$ K. Wojtyła, Osoba i czyn, dz. cyt., s. 58.

${ }^{62}$ Człowiek w polu odpowiedzialności, red. A. Szostek, Lublin 1991, s. 28.

${ }^{63} \mathrm{KDK} 15$. 


\section{Bibliografia}

\section{Źródla drukowane}

Deklaracja o stosunku Kościoła do religii niechrześcijańskich „, Nostra aetate”, w: Sobór Watykański II. Konstytucje, dekrety, deklaracje, Poznań 1968, s. 334-338.

Deklaracja o wolności religijnej „Dignitatis humanae”, w: Sobór Watykański II. Konstytucje, dekrety, deklaracje, Poznań 1968, s. 414-426.

Deklaracja o wychowaniu chrześcijańskim „Gravissimum educationis”, w: Sobór Watykański II. Konstytucje, dekrety, deklaracje, Poznań 1968, s. 313-324.

Dekret o apostolstwie świeckich „Apostolicam actuositatem”, w: Sobór Watykański II. Konstytucje, dekrety, deklaracje, Poznań 1968, s. 379-405.

Dekret o działalności misyjnej Kościoła „Ad gentes divinitus”, w: Sobór Watykański II. Konstytucje, dekrety, deklaracje, Poznań 1968, s. 436-474.

Dekret o ekumenizmie „Unitatis redintegratio”, w: Sobór Watykański II. Konstytucje, dekrety, deklaracje, Poznań 1968, s. 203-218.

Dekret o formacji kaptańskiej „,Optatam totius”, w: Sobór Watykański II. Konstytucje, dekrety, deklaracje, Poznań 1968, s. 286-300.

Dekret o Kościołach wschodnich katolickich „Orientalium Ecclesiarum”, w: Sobór Watykański II. Konstytucje, dekrety, deklaracje, Poznań 1968, s. 181-191.

Jan XXIII, Pacem in terris, Kraków 2003.

Konstytucja dogmatyczna o Kościele „Lumen gentium”, w: Sobór Watykański II. Konstytucje, dekrety, deklaracje, Poznań 1968, s. 105-170.

Konstytucja dogmatyczna o Objawieniu Bożym „Dei verbum”, w: Sobór Watykański II. Konstytucje, dekrety, deklaracje, Poznań 1968, s. 350-363.

Konstytucja duszpasterska o Kościele w świecie wspótczesnym ,, Gaudium et spes”, w: Sobór Watykański II. Konstytucje, dekrety, deklaracje, Poznań 1968, s. 537620.

Konstytucja o liturgii „,Sacrosanctum Concilium”, w: Sobór Watykański II. Konstytucje, dekrety, deklaracje, Poznań 1968, s. 40-70.

Powszechna deklaracja praw człowieka (przyjęta i proklamowana rezolucja Zgromadzenia Ogólnego ONZ 217 A (III) w dniu 10 grudnia 1948), art. 1-30, amnesty.org.pl/wp-content/uploads/2016/04/Powszechna_Deklaracja_Praw_Czlowieka.pdf [dostęp: 10 VI 2020 r.].

\section{Opracowania}

Aubert J.M., Jak żyć po chrześcijańsku w XX wieku?, Warszawa 1986.

Bezner S., Norma personalistyczna jako ,norma normans” moralności w nauczaniu K. Wojtyty, Katowice 2006. 
Chudy W., Między wolnościa prawdziwa a zniewoleniem, „Chrześcijanin w Świecie" 24 (1994), nr 2-3, s. 110-121.

Chudy W., Miejsce prawdy w systemie wartości. Postawa klasyczna a postawa liberalistyczna $i$ ich konsekwencje aksjologiczne, „Chrześcijanin w Świecie” 23 (1993), nr 2, s. 54-62.

Czamara W., Stabość moralna wspótczesnego człowieka a szansa jego moralnej odnowy w ujęciu papieża Jana Pawła II, w: Vivere in Christo. Chrześcijański horyzont moralności. Księga pamiątkowa ku czci Księdza Profesora Seweryna Rosika w 65. rocznicę urodzin, red. J. Nagórny, A. Derdziuk, Lublin 1996, s. 345-369.

Czarny J., Jana Pawła II wizja cywilizacji miłości. Studium filozoficzne, Wrocław 1994.

Człowiek w polu odpowiedzialności, red. A. Szostek, Lublin 1991, s. 28.

Drożdż M., Osoba i media. Personalistyczne paradygmat etyki mediów, Tarnów 2005, s. 50-54.

Galarowicz J., Imię własne człowieka. Klucz do myśli i nauczania Karola WojtytyJana Pawła II, Kraków 1996.

Gałkowski J., O podmiotowym charakterze wspólnoty w ujęciu kard. K. Wojtyły, „Zeszyty Naukowe KUL” 26 (1983), nr 4, s. 3-17.

Gałkowski J., Osoba i wspólnota, „Roczniki Nauk Społecznych” 8 (1980), s. 49-74.

Galarowicz J., Powołani do odpowiedzialności. Elementarz etyczny, Kraków 1993.

Granat W., Personalizm chrześcijański, Poznań 1985, s. 55-60.

Greniu F., Wspótczesna teologia grzechu, „Roczniki Teologiczno-Kanoniczne” 32 (1985), z. 3, s. 81-102.

Greniuk F., Wspólnotowy charakter moralności Ludu Bożego, „Roczniki Teologiczno-Kanoniczne" 24 (1977), z. 3, s. 39-49.

Haring B., Moralność jest dla ludzi. Etyka chrześcijańskiego personalizmu, Warszawa 1975.

Juros H., Moralność, w: Stownik teologiczny, red. A. Zuberbier, Katowice 1998, s. 314-316.

Langkammer H., Godność człowieka wedtug Biblii, w: Życie społeczne w Biblii, red. G. Witaszek, Lublin 1997, s. 9-21.

Mazurek F., Godność osoby ludzkiej jako źródto praw człowieka i obywatela, „Civitas et Lex" (2014), nr 1, s. 41-47.

Moralność chrześcijańska, t. 2, red. P. Góralczyk, Poznań-Warszawa 1987.

Mroczkowski I., Misterium czlowieka stworzonego, „Roczniki Teologiczne” 40 (1993), z. 3, s. 31-40.

Mroczkowski I., Wolność na miarę wiary, nadziei i miłości, „Chrześcijanin w Świecie" 20 (1988), nr 4-5, s. 102-117. 
Nagórny J., Kazanie na górze (Mt 5-7) jako moralne orędzie Nowego Przymierza, „Rocznik Teologii Katolickiej” 32 (1985), z. 3, s. 5-21.

Nagórny J., Teologiczna interpretacja moralności Nowego Przymierza, Lublin 1989.

Nagórny J., Trynitarny fundament życia moralnego w ujęciu św. Pawta, „Rocznik Teologii Katolickiej” 39 (1982), s. 47-56.

Olejnik S., W kręgu moralności chrześcijańskiej, Warszawa 1985.

Pieja W., Moralność chrześcijańska w zderzeniu z obojętnościa religijną, Tarnów 2018.

Pinckaers T., Źródta moralności chrześcijańskiej. Jej metoda, treść, historia, Poznań 1994.

Pizzorni R.M., Dio fondamento ultimo della morale e del diritto, „Sapienza” 49 (1996), s. 435-448.

Rosik S., Wezwania i problemy moralne. Refleksje teologiczno-moralne, Lublin 1992.

Smoleński S., Powołanie chrześcijańskie. Zarys teologii moralnej, t. 1, Kraków 1978.

Witek S., Chrześcijańska wizja moralności, Poznań 1982.

Wojtyła K., Osoba i czyn, Kraków 1969.

\section{Streszczenie}

Celem publikacji jest ukazanie integralności moralności i kultury. Zgodność ta nie jest w pełni możliwa bez uwzględnienia koncepcji godności osoby ludzkiej. Obok koncepcji deontologicznej zostaje ukazane wielkie dobro kultury, jakim są sakramenty. Normą moralności jest godność osoby ludzkiej, która wynika z faktu stworzenia i odkupienia przez Jezusa Chrystusa i staje się dla niego norma normans, ale dotyczy także rozwoju osoby. Godność osoby ludzkiej polega na przekraczaniu świata stworzonego, posiadaniu duszy nieśmiertelnej, korzystaniu z władz rozumu, zdobywaniu prawdy, słuchaniu głosu sumienia. Godność osoby ludzkiej zostaje pogłębiona w świetle objawienia, w którym człowiek odnajduje swoje powołanie. Dobrem kultury są sakramenty i cnoty. Człowiek jako osoba daje odpowiedź na Boże wezwanie, szanując godność swoją, drugiego człowieka, wolne decyzje drugiego, jest odpowiedzialny. Gaudium et spes przytacza na końcu syntezę godności rozumu, prawdy i mądrości człowieka: „Człowiek, z racji swej godności osoby ludzkiej, uczestnicząc w Bożej myśli, góruje swym rozumem nad światem rzeczy”.

Słowa klucze: moralność, kultura, godność człowieka, godność osoby ludzkiej, Gaudium et spes 


\section{Integrity of Morality, Culture and Human Dignity in Vatican II's Gaudium et Spes}

\section{Summary}

This aim of this article is to show the integrity of morality and culture. This compatibility is not fully possible without taking into account the concept of human dignity. Apart from discussing the concept of deontological, the author also presents the great cultural good, that is the sacraments. The norm of morality is the dignity of the human person, which results from the fact of creation and redemption by Jesus Christ, which becomes the norma normans for him but also concerns the development of the person. The dignity of the human person consists in transcending the created world, having an immortal soul, exercising the powers of reason, gaining truth, and listening to the voice of conscience. The dignity of the human person is deepened in the light of revelation in which man finds his vocation. The sacraments and virtues are cultural goods. Man as a person responds to God's call, respecting his own and others dignity, as well as the free decisions of others and his responsible. Gaudium et spes finally gives a synthesis of the dignity of human reason, truth and wisdom: "Man, by virtue of his dignity as a human person, by participating in God's thought, triumphs over the world of things with his reason.

Key words: morality, culture, man's dignity, dignity of the human person, Gaudium et spes 
